\title{
Prolonged $\beta$-Agonist Infusion Does Not Induce Desensitization or Down-Regulation of $\beta$-Adrenergic Receptors in Newborn Sheep
}

\author{
HOWARD M. STEIN, KOTARO OYAMA, ROBERT SAPIEN, BARBARA A. CHAPPELL, AND \\ JAMES F. PADBURY \\ Perinatal Research Laboratories, Department of Pediatrics, Harbor-UCLA Medical Center, UCLA School of \\ Medicine, Torrance, California 90502
}

\begin{abstract}
In adult animals, prolonged $\beta$-agonist exposure leads to down-regulation of $\beta$-adrenergic receptors and desensitization. Prior evidence from our lab suggests that this may not occur in developing animals. To study this, we measured the response to graded epinephrine infusion $[2.7,5.5,13.6,27.3 \mu \mathrm{mol} /(\mathrm{kg} \cdot \mathrm{min}),(0.5,1.0,2.5,5.0 \mu \mathrm{g} /$ (kg-min)], myocardial $\beta$-agonist receptor density, and components of the receptor-cyclase system in newborn lambs before $(n=6)$ and after $(n=5) 3 \mathrm{~d}$ of continuous isoproterenol administration $(2 \mu \mathrm{g} / \mathrm{kg} / \mathrm{min})$. $\beta$-Adrenergic receptors were measured by radioligand binding. Epinephrine dose-response curves were analyzed for the threshold and slope for changes in mean blood pressure, systolic blood pressure, and heart rate versus plasma epinephrine levels. Despite $3 \mathrm{~d}$ of continuous isoproterenol infusion, we observed no desensitization of the hemodynamic response to epinephrine. There was a reduction in receptor density when expressed per membrane protein $[155.3 \pm 19.5$ (controls) versus $73.2 \pm 3.8 \mathrm{fmol} / \mathrm{mg}$ protein (agonist exposed), $p<0.05$, but no alteration in receptor density when expressed per $\mathrm{g}$ cardiac wet weight $[258.8 \pm 39.9$ (controls) versus $406.8 \pm 74.0 \mathrm{fmol} / \mathrm{g}$ wet weight (agonist exposed)]. There was no alteration in agonist affinity or in adenylyl cyclase activity after adjustment for membrane protein recovery. Prolonged $\beta$-agonist infusion in newborn lambs does not desensitize hemodynamic responses to infused epinephrine. We propose that receptor regulation in developing animals is fundamentally different than in adult animals. (Pediatr Res 31: 462-467, 1992)
\end{abstract}

\section{Abbreviations}

BAR, $\beta$-adrenergic receptor

ISO, isoproterenol

GTP, guanosine triphosphate

DHA, dihydroalprenolol

$G_{s}$, guanyl nucleotide stimulatory protein

Adrenergic receptors are the effectors through which catecholamines exert their effects on their target organs. Agonist binding to $\beta$-adrenergic receptor results in an increase in intracellular cAMP mediated via guanine nucleotide regulatory proteins and the catalytic enzyme adenylyl cyclase (1). Multiple investigators

Received September 24, 1991; accepted December 18, 1991.

Correspondence: James F. Padbury, M.D., Harbor-UCLA Medical Center, 1000 W. Carson St., Torrance, CA 90502.

Supported in part by grants from the USPHS, HD 18014 and HD 07013, and an Investigative Group Fellowship Award from the American Heart Association, Los Angeles, CA. have demonstrated alteration of $\beta$-adrenergic-mediated responses after chronic agonist exposure. Decreased responsiveness, known as desensitization, may result from alteration in several components of the hormone-responsive adenylate cyclase system. These include down-regulation or a decrease in adrenergic receptor numbers, a shift in the ratio of affinity states of the receptor, altered coupling of the receptor and $\mathrm{G}$ protein, altered expression of $\mathrm{G}$ proteins, altered adenylyl cyclase activity, or alterations of intracellular systems distal to the second messenger (2-5). In vitro and in vivo studies in adult models have used both pharmacologic agents and physiologic stimuli to demonstrate alteration at each of these levels.

In developing animals, studies on desensitization have been less confirmatory. Investigators from several laboratories have noted little or no apparent desensitization or alteration in receptor numbers after agonist administration or physiologic elevations of endogenous catecholamines (6-10). Previous in vivo data from our laboratory have shown that there is no change in $\beta$ receptor density of lamb myocardial cells or alteration in adenylyl cyclase activity after exposure to the logarithmic increases in catecholamines at birth (9) or in response to severe chronic intrauterine stress $(10)$. In newborn rats, there is no alteration in receptor numbers, density affinity, or response to $\beta$-agonists after sustained increases in sympathetic nerve activity (6). It is possible that this absence of "homologous" or agonist-induced receptor regulation may be unique to certain phases of development.

We therefore designed experiments to determine the effect of long-term exogenous $\beta$-agonist exposure in developing animals on BAR responsiveness. We evaluated $\beta$-agonist-mediated physiologic responses before and after prolonged agonist exposure, changes in myocardial receptor density, alterations in $\mathrm{G}$ proteinmediated receptor-cyclase coupling, and adenylyl cyclase activity.

\section{MATERIALS AND METHODS}

We studied 11 Barbados lambs at $25 \pm 3 \mathrm{~d}$ of age. Five animals were used for the study and six animals were the controls. Animals had femoral arterial and venous catheters placed under ketamine anesthesia and local $2 \%$ lidocaine infiltration. The catheters were then tunneled s.c. and exteriorized into a flank pouch. The lambs were allowed a 2- to 3-d recovery period, during which time they received i.v. oxacillin $(100 \mathrm{mg} / \mathrm{kg})$ and gentamicin $(2 \mathrm{mg} / \mathrm{kg})$ twice a day. The animals were housed with their mothers and allowed to feed ad libitum. They were also acclimated to the laboratory staff and environment.

Epinephrine dose-response curves. Baseline epinephrine doseresponse curves were obtained before prolonged agonist infusion as previously described from this laboratory $(11,12)$. All animals were awake, unanesthetized, and calm in a restraining sling. Before sampling, the animals were allowed 30-60 min for heart 
rate and blood pressure to stabilize. Baseline blood pressure, heart rate, plasma epinephrine, and glucose levels were obtained. An infusion was initiated via the venous line at $2.7 \mu \mathrm{mol} /(\mathrm{kg}$. $\min )[0.5 \mu \mathrm{g} /(\mathrm{kg} \cdot \min )]$ and repeat biophysical measurements and samples were obtained at 15 and $30 \mathrm{~min}$. Previous data from our laboratory have demonstrated steady state plasma epinephrine concentration by $15 \mathrm{~min}$. The infusate concentration was adjusted to provide graded doses of $2.7,5.5,13.6$, and $27.3 \mu \mathrm{mol} /$ $(\mathrm{kg} \cdot \min )[0.5,1.0,2.5$, and $5.0 \mu \mathrm{g} /(\mathrm{kg} \cdot \mathrm{min})]$. Each dose was infused for $30 \mathrm{~min}$. Biophysical measurements and plasma collections were obtained at 15 and $30 \mathrm{~min}$ after the start of each dose. All infusions were administered at $0.33 \mathrm{~mL} / \mathrm{min}$.

When the dose-response curve was concluded, the animal was started on a continuous i.v. infusion of ISO at $2 \mu \mathrm{g} / \mathrm{kg} / \mathrm{min}$. This dose was chosen from previous studies as effective in inducing short-term down-regulation of BAR in adults (13). We used an Auto Syringe Model AS30C Ambulatory Infusion Pump (Baxter Laboratories, Morton Grove, IL), which was stored in the flank pouch. Animals were moved to the laboratory daily and placed in the restraint sling. The reservoir was changed daily, during which time a biophysical profile was done to confirm a pharmacologic response (increased heart rate and blood pressure) to the ISO. After $60 \mathrm{~h}$, the infusion was discontinued and the animals allowed a $2-$ to $3-h$ resting period. They were then taken to the laboratory, and the epinephrine dose-response curve was repeated.

To maximize differences in agonist-exposed and control animals, the control animals underwent identical surgical procedures and recovery. The controls were not, however, infused with epinephrine or ISO.

Analytical techniques. One $\mathrm{mL}$ of blood taken at each sampling was transferred immediately to chilled test tubes containing 4 $\mathrm{mM}$ EGTA and reduced $3 \mathrm{mM}$ glutathione. The tubes were mixed and centrifuged immediately at $4^{\circ} \mathrm{C}$ and the plasma was separated and stored at $-70^{\circ} \mathrm{C}$ for later assay. Plasma epinephrine levels were determined by radio enzymatic assay sensitive to $10-$ $20 \mathrm{pg} / \mathrm{mL}$ (14). Plasma glucose levels were measured by a YSI model 23A glucose analyzer (Yellow Springs Instrument Co., Yellow Springs, $\mathrm{OH})$.

Postmortem studies. After completion of all infusion protocols, animals were killed by pentobarbital overdose. The heart was removed rapidly via a midline thoracotomy incision. The ventricular tissue was harvested, weighed, and processed for the BAR assay as previously described $(9,15)$. Briefly, the ventricles were washed in ice-cold buffer and homogenized using a Tekmar (Cincinnati, OH) tissuemizer at high speed for $60 \mathrm{~s}$. The homogenate was centrifuged at $3000 \times g$ for $10 \mathrm{~min}$. The supernatant was decanted, saved, and centrifuged at $40000 \times g$ for $20 \mathrm{~min}$ at $4^{\circ} \mathrm{C}$. The resulting pellet was resuspended and recentrifuged at $40000 \times g$ for $20 \mathrm{~min}$. The final pellet was resuspended to a final concentration of $1-2 \mathrm{mg}$ protein $/ \mathrm{mL}$ with a Teflon glass homogenizer. The homogenate was separated into $2-\mathrm{mL}$ aliquots, quick frozen with dry ice and ethanol, and stored at $-70^{\circ} \mathrm{C}$ until assay. Protein concentration of the membrane suspensions was determined by the method of Lowry (16).

Direct binding studies. Direct binding studies for BAR were performed on the partially purified membranes as previously reported from this laboratory $(9,15)$. Membrane fractions, incubation buffer, and graded concentrations of tritiated dihydroalprenolol (sp act $50-55 \mathrm{Ci} / \mathrm{mmol}$ ) ranging from 1 to $10 \mathrm{nM}$ with or without $d, l$-propranolol $(1 \mu \mathrm{mol})$ were incubated for $20 \mathrm{~min}$ at $30^{\circ} \mathrm{C}$. Bound and free material were separated by rapid filtration using Whatman GF/C glass filters. The filters were then dried and counted in toluene liquifluor. Nonspecific binding was defined as the amount of $\left[{ }^{3} \mathrm{H}\right] \mathrm{DHA}$ bound in the presence of propranolol.

The state of BAR for agonist binding was assessed by incubating membrane fractions with graded ISO concentrations $\left(10^{-3}\right.$ to $10^{-9} \mathrm{M}$ ) and $\left[{ }^{3} \mathrm{H}\right] \mathrm{DHA}(5 \mathrm{nM})$ for $20 \mathrm{~min}$ at $30^{\circ} \mathrm{C}$. The material was rapidly filtered and counted as described above.
Adenylyl cyclase activity. Adenylyl cyclase activity was determined in the partially purified myocardial membrane preparations from control and study animals. Before assay, the membrane preparation was resuspended in an incubation buffer and $80-120 \mu \mathrm{g}$ of the resuspended membrane preparation were incubated in the presence of GTP $\left(10^{-5}\right)$ with phosphocreatinine $(12 \mathrm{mM})$, creatinine phosphokinase $(30 \mu \mathrm{g} / \mathrm{tube})$, ATP $(1 \mathrm{mM})$, and with ISO concentrations ranging from $10^{-3}$ to $10^{-6} \mathrm{M}$. The GTP concentration chosen was based on preliminary experiments demonstrating maximal agonist-mediated adenylyl cyclase activity (9). $\mathrm{G}_{\mathrm{s}}$-dependent adenylyl cyclase activity was determined in the presence of sodium fluoride $(10 \mathrm{mM})$. Total cyclase activity was determined in the presence of forskolin $(0.1 \mathrm{mM})$. After incubation at $30^{\circ} \mathrm{C}$ for $20 \mathrm{~min}$, the tubes were immersed in ice and then boiled for $3 \mathrm{~min}$. The incubates were centrifuged at $1000 \times g$ for $20 \mathrm{~min}$ and the cAMP in the supernatant was determined by RIA using a commercially available kit (New England Nuclear-DuPont, Boston, MA). This assay has a withinassay variation of $4.3 \%$, a between-assay variation of $9.8 \%$, and a sensitivity of approximately $0.2 \mathrm{pmol} / \mathrm{mL}$. Cross-reactivity with a variety of other nucleotides is less than $0.02 \%$.

Besides adenylyl cyclase, we used the presence of oubaininhibitable sodium-potassium ATPase activity as an additional membrane-associated enzyme activity. The membrane-associated sodium-potassium ATPase activity is represented by total activity minus that inhibited by oubain. The membrane preparations were resuspended in buffer $(0.25 \mathrm{M}$ sucrose, $1.25 \mathrm{mM}$ EGTA, $10 \mathrm{mM}$ Tris) and incubated as previously described (17). Phosphate was determined using a modification of the method of Fiske and Subbarow (18). Protein content was determined by the method of Lowry (16).

Data analysis. Individual dose-response curves (relating heart rate or blood pressure to plasma epinephrine concentration) were analyzed before and after each 60-h ISO infusion. A computerized graphic analysis using a nonlinear, least squares regression method was used to compare the hemodynamic response and the plasma epinephrine levels. It has been demonstrated that there is no change in physiologic response until a "threshold" plasma catecholamine concentration is reached $(11,19)$. Beyond the threshold, a linear increase in the response for logarithmic increase in the plasma epinephrine concentration was assumed. The minimal epinephrine level above which there are discernible physiologic responses is the threshold. Parameters derived from the dose-response curves pre- and post-ISO infusion were compared using the paired $t$ test.

BAR characteristics were determined by Scatchard analysis using a computer program that determines maximum binding capacity and the dissociation constant (LIGAND, 20). Agonist binding data were analyzed using LIGAND to determine the percentage of receptors in the high-affinity state $(R h / R h+R 1$, where $\mathrm{Rh}$ represents the number of receptors in the high-affinity state and R1 represents the number of receptors in the lowaffinity state). Receptor density and cAMP activity were normalized to protein concentration in the membrane preparation. Recovery of membrane protein from the cardiac wet weight was determined for both control and agonist-exposed animals. Receptor density and cAMP activity were then normalized to cardiac wet weight. Receptor number, the percentage in the high-affinity state, and adenylyl cyclase activity were compared using unpaired $t$ test. All data are expressed as mean \pm SEM except for catecholamines, which are presented as geometric mean \pm SEM.

\section{RESULTS}

All ISO-infused animals underwent epinephrine dose-response studies both before and after the ISO infusions. During the ISO infusions, there were significant hemodynamic responses. Baseline heart rate and systolic blood pressure (182 $\pm 11.1 \mathrm{bpm}$ and $101 \pm 6.4 \mathrm{~mm} \mathrm{Hg}$, respectively) increased to $232 \pm 12.4 \mathrm{bpm}$ and $134 \pm 8.7 \mathrm{~mm} \mathrm{Hg}$ during the ISO infusion $(p<0.02)$. Figure 
1 shows the dose-response curves for epinephrine administration versus systolic blood pressure for a representative animal before and after the 60-h ISO infusion. As can be seen, the dose-response curves are virtually identical. All animals displayed good agreement between the anticipated log-linear threshold model and the actual data. it was from these curves that the thresholds for blood pressure and heart rate are calculated. For an increase in systolic blood pressure, the mean threshold was $27 \pm 6 \mathrm{pmol} / \mathrm{L}$ of epinephrine before ISO infusion and $14 \pm 8 \mathrm{pmol} / \mathrm{L}$ after ISO infusion $(p=0.3)$. The slope was $173 \pm 29$ pre- and $122 \pm 19$ $\mathrm{mm} \mathrm{Hg} /(\mathrm{pmol} \cdot \mathrm{L})$ postinfusion $(p=0.3)$. For mean blood pressure, the results were similar. The heart rate response was variable. Some animals displayed an increase in heart rate, whereas others exhibited a reflex bradycardia at the higher epinephrine doses. The threshold and slope for all hemodynamic parameters were not statistically different pre- and post-ISO infusion, thus indicating a lack of desensitization.

An increase in circulating blood glucose concentration is a predictable metabolic response to epinephrine infusion. These responses are mediated in part by direct adrenergic mechanisms. In Figure 2, the blood glucose responses to epinephrine infusion before and after the ISO infusion are shown for one of the animals. As can be seen, there was a prompt and sustained increase in blood glucose concentration in the animals before ISO infusion. However, after $60 \mathrm{~h}$ ISO infusion, there was no increase in blood glucose concentration during epinephrine infusion. These results are representative of responses in each of the animals studied. In contrast to hemodynamic responses, which were unaltered, blood glucose responses were obtunded or abolished by prolonged ISO infusion.

Figure 3 is a representative saturation binding curve and Scatchard plot. The wet weight of the hearts recovered from the control and the study animals $(31.5 \pm 1.9$ versus $32.8 \pm 1.0 \mathrm{~g})$ were similar. There was, however, a difference in recovery of membrane protein between the two groups. The amount of membrane protein recovered increased from $1.7 \pm 0.2$ to $5.5 \pm$ $0.8 \mathrm{mg}$ protein $/ \mathrm{g}$ cardiac wet weight $(p<0.01)$ after ISO infusion. There was no change in receptor density when expressed in fmol/ $\mathrm{g}$ cardiac wet weight $[258.8 \pm 39.9$ in the controls versus 406.8 \pm 74.0 in the agonist-exposed group $(p=0.13)]$. There was, however, a decrease in receptor density when expressed as fmol/ $\mathrm{mg}$ protein $[155.3 \pm 19.5$ in the controls versus $73.2 \pm 3.8$ in the agonist-exposed group $(p<0.01)]$. The $\mathrm{k}_{\mathrm{d}}$ of the control group

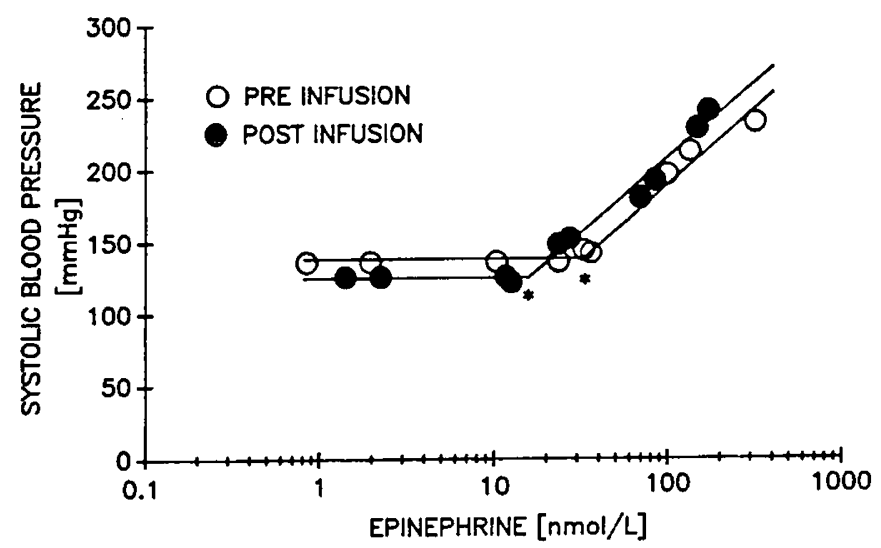

Fig. 1. Dose-response curve showing systolic blood pressure vs log plasma epinephrine concentration for a single animal before $(O)$ and after ( $60 \mathrm{~h}$ of continuous ISO infusion. There is no increase in systolic blood pressure until a certain plasma level of epinephrine or threshold $(*)$ is reached. A log-linear response is then observed. The threshold and slope are determined from a computerized graphic analysis using a nonlinear, least squares regression method. The dose-response curves are virtually identical pre- and post-ISO infusion with respect to baseline and peak leveis, slope, and threshold. All animals displayed a similar lack of desensitization.

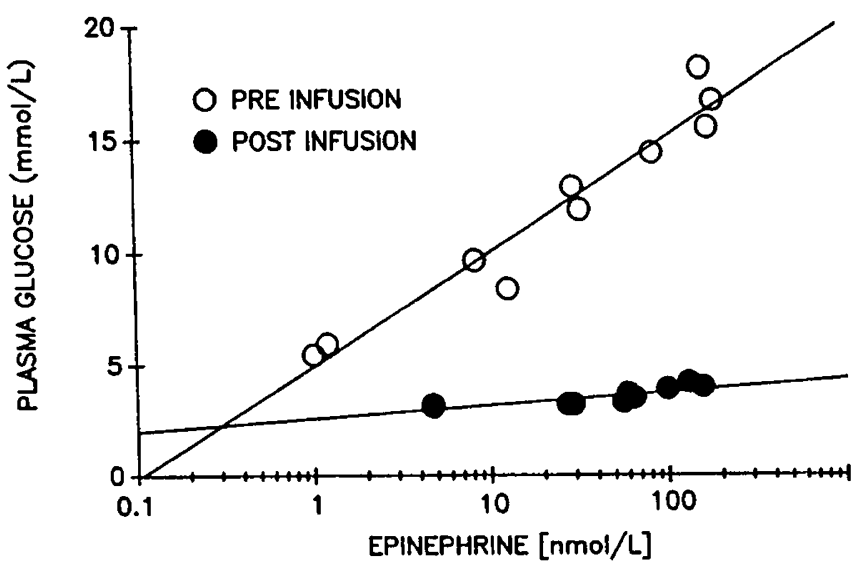

Fig. 2. Blood glucose response vs log plasma epinephrine concentration for a single animal. There is a sustained log-linear increase in blood glucose pre (O)-ISO infusion to infused epinephrine. After $60 \mathrm{~h}$ of ISO infusion (๑), there is essentially no increase in blood glucose concentration to infused epinephrine. All animals displayed a similar obtundation after ISO infusion.

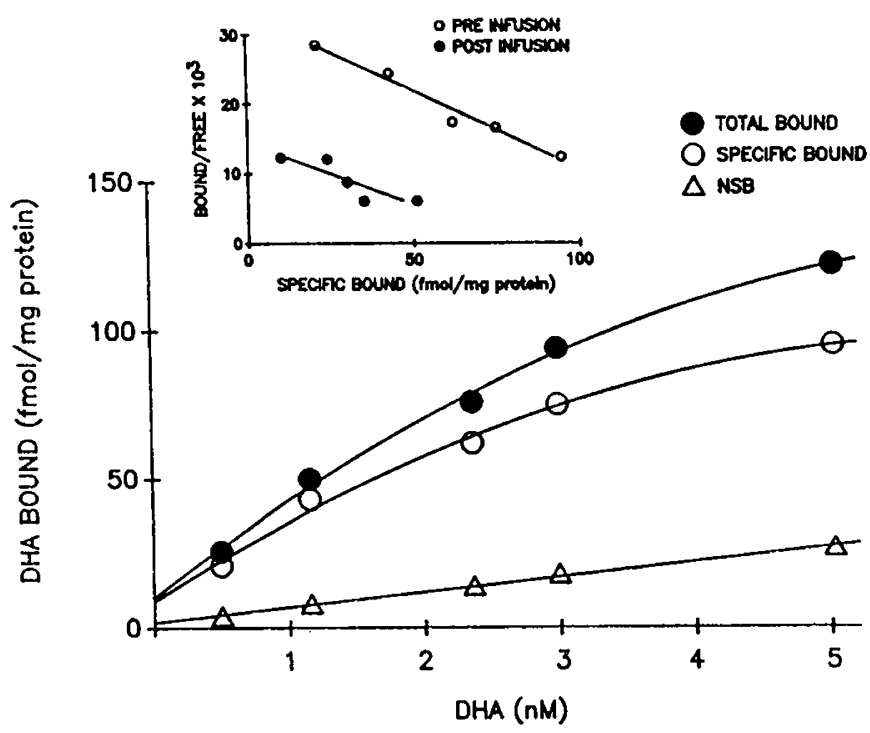

Fig. 3. Representative saturation binding curve for myocardial tissue from a single animal. All animals displayed similar binding characteristics. The insert is a scatchard analysis of representative myocardial tissues before $(O)$ and after $(\Theta) 60 \mathrm{~h}$ of continuous ISO infusion. The slopes $\left(\mathrm{k}_{\mathrm{d}}\right)$ are similar, but there is a decrease in the maximal binding capacity, expressed as $\mathrm{fmol} / \mathrm{mg}$ protein after ISO infusion. This decrease is no longer apparent when maximal binding capicity is expressed as $\mathrm{fmol} / \mathrm{g}$ cardiac wet weight.

was $3.4 \pm 0.8 \mathrm{nM}$ and did not change in the agonist-exposed group $(3.7 \pm 0.7 \mathrm{nM})$.

Figure 4 displays the agonist competition curves from all the animals for ISO versus $\left[{ }^{3} \mathrm{H}\right]$ DHA. The proportion of receptors in the high- and low-affinity states and their respective affinity constants are shown in Table 1. Before ISO infusion, $68 \pm 5 \%$ of cardiac $\beta$-receptors were in the high-affinity state. This did not change after $60 \mathrm{~h}$ of ISO infusion $(55 \pm 5 \% ; p=0.09)$.

The adenylyl cyclase activity before and after $60 \mathrm{~h}$ of ISO infusion is illustrated in panels $A$ and $B$ of Figure 5. As can be seen in panel $A$, the control group had a significant increase from baseline adenylyl cyclase activity with the addition of GTP. When ISO was added, there was a 4-fold increase in adenylyl cyclase activity. Incubation in the presence of $\mathrm{NaF}$ and forskolin resulted in further increases in adenylyl cyclase activity. This indicates an intact receptor-cyclase system. In the study group, 


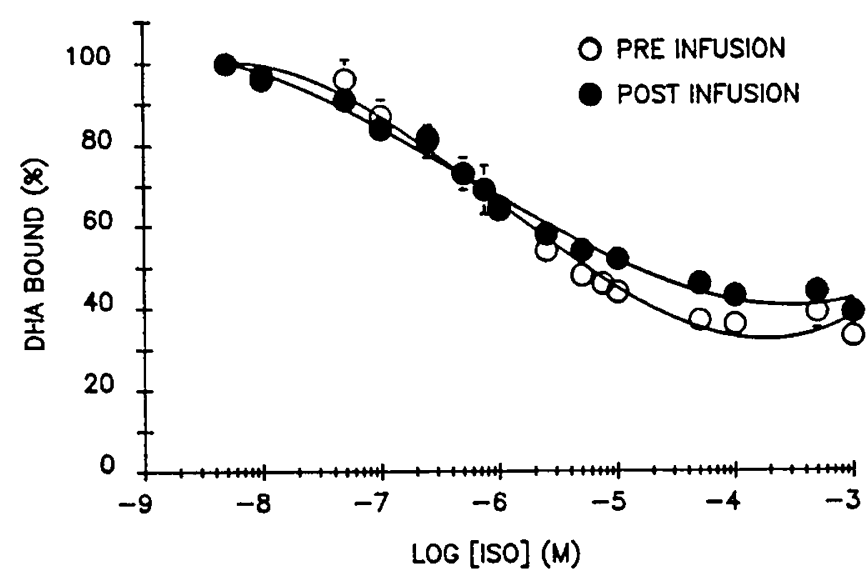

Fig. 4. Agonist competition curves for all the animals for isoproterenol vs DHA. There is no change in the \% of receptors in the high-affinity state after $60 \mathrm{~h}$ of ISO infusion.

Table 1. High-and low-affinity constants and percentage of receptors in high-and low-affinity states before and after $60 \mathrm{~h}$ of

\begin{tabular}{lccl}
\multicolumn{4}{c}{ ISO infusion* } \\
\hline & Preinfusion & Postinfusion & $p$ \\
\hline $\mathrm{Kh}(\mathrm{nM})$ & $25.6 \pm 11.8$ & $16.3 \pm 4.6$ & 0.5 \\
$\mathrm{Kl}(\mathrm{M})$ & $5.2 \pm 5.0$ & $12 \pm 11$ & 0.6 \\
$\mathrm{Rh} / \mathrm{Rh}+\mathrm{Rl}(\%)$ & $54.5 \pm 5.0$ & $68.0 \pm 5.0$ & 0.09 \\
$\mathrm{Rl} / \mathrm{Rh}+\mathrm{Rl}(\%)$ & $45.5 \pm 5.3$ & $32.0 \pm 4.8$ & 0.09 \\
\hline
\end{tabular}

${ }^{*} \mathrm{Kh}$, high-affinity constant; $\mathrm{Kl}$, low-affinity constant; $\mathrm{Rh}$, number of receptors in the high-affinity state; and $\mathrm{Rl}$, number of receptors in the low-affinity state.

the basal activity was the same as the control. However, there was no increase in adenylyl cyclase activity with the addition of GTP, and only a modest increase with the addition of ISO or $\mathrm{NaF}$. There was an increase in total cyclase activity (forskolin), but not as pronounced as in the control group. Overall, there was a significant reduction in adenylyl cyclase activity in the study group when compared with the control group if expressed per mg protein. When the adenylyl cyclase activity is expressed per $\mathrm{g}$ cardiac wet weight (as seen in panel $B$ ), the $\beta$-agonistmediated (ISO), NaF-mediated and forskolin-mediated increases above baseline all remained significant, again indicating an intact receptor-cyclase system. There were, however, no differences between control and ISO-infused animals, except for $\operatorname{NaF}(p=$ 0.02 ).

Figure 6 demonstrates the phosphate production with and without ouabain, and the membrane-associated sodium-potassium ATPase activity expressed as $\mu \mathrm{mol}$ phosphate/(mg protein . h). There is ouabain-inhibitable activity in both groups, although less in the postinfusion group. If expressed per $\mathrm{g}$ cardiac wet weight, these differences are no longer apparent.

\section{DISCUSSION}

We undertook the present studies to determine whether regulation of adrenergic receptor responsiveness, number, or function was fundamentally different in newborn animals than in adult animals. We evaluated responsiveness to adrenergic receptor stimulation by comparison of dose-response data to infused epinephrine before and after prolonged ISO infusion. Myocardial BAR density and function were compared in ISO-infused and control animals, as well as functional status of the receptoradenylyl cyclase system.

We observed no significant alteration in hemodynamic responses to infused epinephrine after $60 \mathrm{~h}$ of continuous infusion of ISO. There was no change in epinephrine threshold for blood pressure and no change in the maximum blood pressure at
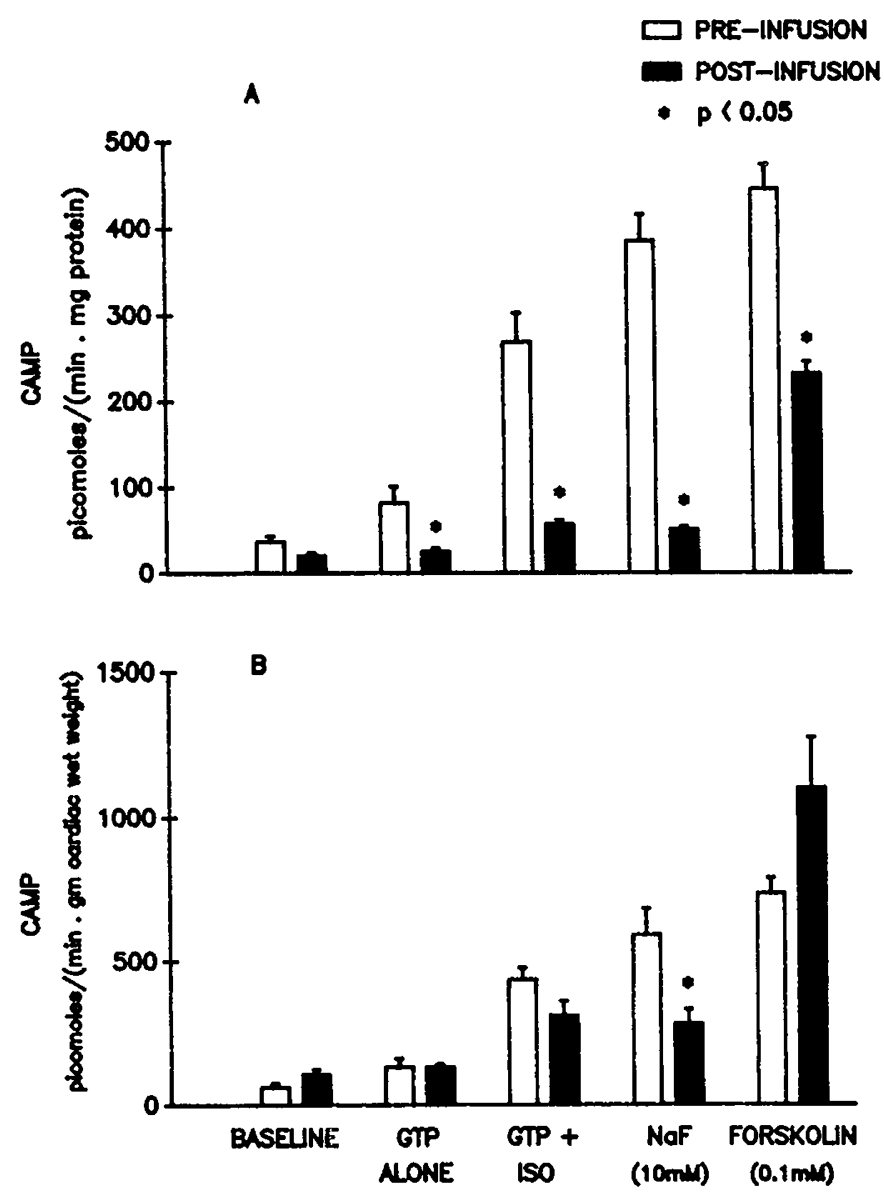

Fig. 5. $A$, Adenylyl cyclase activity after incubation with various substrates expressed as $\mathrm{pmol} /(\mathrm{min} \cdot \mathrm{mg}$ protein). The increase in cAMP production from baseline in the presence of various incubations confirms the presence of an intact receptor-cyclase system. Baseline activity is similar before ( $\square$ ) and after $(\square) 60 \mathrm{~h}$ of ISO infusion. However, all other. incubations post-ISO infusion demonstrate significantly decreased cAMP formation compared to pre-ISO infusion. These differences are proportional to the alteration in membrane protein recovery observed after ISO infusion. If expressed per $g$ cardiac wet weight, there is no change in adenylyl cyclase activity pre- $v s$ post-ISO infusion $(B)$.

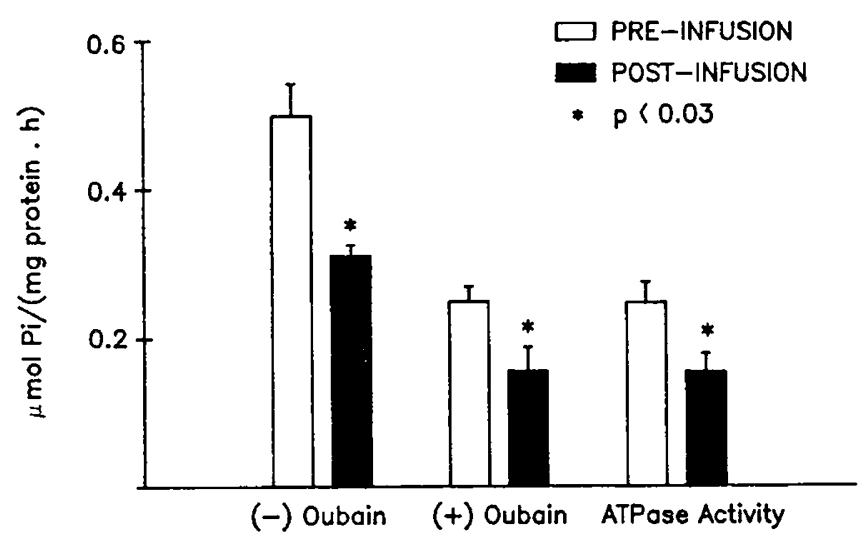

Fig. 6. Ouabain-inhibitable sodium-potassium ATPase activity. If expressed as $\mu \mathrm{mol} /(\mathrm{mg}$ protein $\cdot \mathrm{h})$, the phosphate production with and without ouabain is lower in the ISO-infused ( $\square$ ) animals. The membraneassociated ATPase activity is reflected as phosphate production without ouabain minus with ouabain. 
comparable doses. Furthermore, there was no change in the slope of the dose-response curve relating plasma epinephrine level to observed response. This is in marked contrast to results in adult animals and humans, where agonist exposure significantly obtunds hemodynamic responses $(6,21-24)$.

When adrenergic receptor density was expressed per $\mathrm{mg}$ of membrane protein, there was a reduction in receptor density of $53 \%$. However, if expressed per mg of cardiac wet weight, there was no apparent reduction in receptor density. Adenylyl cyclase is a membrane-bound enzyme coupled to several hormonereceptor systems, including $\operatorname{BAR}(4,5)$. There was a reduction in $\beta$-agonist-mediated adenylyl cyclase activity and $\mathrm{G}_{\mathrm{s}}$-dependent adenylyl cyclase activity, but these reductions were proportional to the alteration in membrane protein. As was true for receptor density, if expressed per $\mathrm{g}$ tissue wet weight, there was no reduction in adenylyl cyclase activity or in the other membrane marker, sodium-potassium ATPase activity. Our results may be explained by alteration in the distribution of cardiac protein between membrane and contractile elements. The observed increase in protein recovery may reflect an increase in sarcolemmal elements and a reduction in contractile elements. Therefore, if there has been a change in protein distribution, density of a primarily membrane-associated marker may or may not reflect actual alteration in expression or function of that moiety. We believe that this accounts in part for the remarkable absence of desensitization.

The majority of studies of receptor regulation have been conducted in adult animals or humans exposed to pharmacologic doses of exogenous agonists $(1-3,25)$. In contrast, studies relying on physiologically induced changes in endogenous catecholamines yield different results. There is no change in BAR density, but there is a reduction in cAMP generation and a change in the proportion of receptors in the high-affinity, $\mathrm{G}_{\mathrm{s}}$-coupled state, from 85 to $60 \%$ (26). In adult animals and humans, in the majority of tissues and systems evaluated, BAR in the native state exist predominantly in the high-affinity state with respect to agonist binding and adenylyl cyclase activation (1,3). A rapid conformational change to the low-affinity state probably represents an important short-term mechanism for attenuation of catecholamine responsiveness. This contrasts with our data, which demonstrate a lower initial proportion of high-affinity receptors and no significant alteration in agonist affinity state despite prolonged pharmacologic doses of ISO. Our data are consistent with the interpretation that receptor phosphorylation may not be expressed in developing animals at the ages studied by ourselves and others $(6-10)$.

Studies of receptor regulation in young or newborn animals suggest that classical, agonist-mediated alteration in receptor density and function may be different in developing animals. In newborn rats, ISO administration is not accompanied by altered myocardial $\beta$-receptor density or sensitivity until after 3-4 wk of life, when development of the cardiac sympathetic axis is complete (6). In mature rats, identical treatment results in adrenergic subsensitivity and reduced receptor density (6). We previously evaluated receptor density in two sheep models associated with increased levels of circulating catecholamines. In the first model, we evaluated the effect of the 5- to 10-fold increases in endogenous catecholamines at birth on the cardiac adrenergic receptor system. Despite logarithmic increases in both norepinephrine and epinephrine more than $6 \mathrm{~h}$ after birth, there was no alteration in receptor density or the receptor-cyclase system (9). In a subsequent study, we subjected immature fetal sheep to single umbilical artery ligation, a form of chronic intrauterine stress (27). Despite severe growth retardation, there was only subtle alteration in cardiac performance at birth and no alteration in receptor density, receptor cyclase coupling, proportion of highaffinity sites or cAMP formation (10). Furthermore, other investigators have shown that in human newborns, there was no significant relation between the degree of increase in circulating plasma catecholamine levels at birth and receptor density or ISO- induced cAMP formation on circulating mononuclear lymphocytes (7).

Recently, the effect of prolonged ( $3 \mathrm{~d}$ ) ritodrine administration on $\beta$-receptor-mediated response in fetal sheep has been evaluated (28). Metabolic responses, including epinephrine-induced increases in glucose, FFA, lactate, and glucagon, were indeed obtunded. However, hemodynamic responses were only marginally affected. Direct investigations of receptor number and function were not carried out. In neither the former nor present study were glycogen or adipose tissue stores evaluated. Taken together with our hemodynamic data, we believe that depletion of substrate stores rather than alteration in receptor density and responsiveness accounts for the metabolic observations in both studies.

In summary, we evaluated adrenergic receptor responsiveness, receptor density, and multiple components of the receptor-cyclase system in newborn sheep before and after prolonged ISO infusion. There was no desensitization of the hemodynamic responses to infused epinephrine. Myocardial receptor density was reduced when expressed on the basis of membrane protein, but total receptor number, represented as density per $\mathrm{g}$ cardiac wet weight, was not reduced. Agonist-mediated cAMP generation was similarly reduced when expressed per membrane protein, but not per g cardiac wet weight. We speculate that receptor regulation is fundamentally different in developing animals. Evaluation of the precise nature of the regulatory alterations should lead to important insights into receptor regulation.

Acknowledgments. The authors thank Siang Thio, Elizabeth Buhl, and Leslie Blount for their expert technical assistance and Sharon Schuler for preparation of the manuscript.

\section{REFERENCES}

1. Raymond JR, Hnatowich M, Lefkowitz RJ, Caron MG 1990 Adrenergic receptors: models for regulation of signal transduction processes. Hypertension 15:119-131

2. Exton JH 1985 Role of calcium and phosphoinositides in the actions of certain hormones and neurotransmitters. J Clin Invest 75:1753-1757

3. Hausdorff WP, Caron MG, Lefkowitz RJ 1990 Turning off the signal: desensitization of $\beta$-adrenergic receptor function. FASEB J 4:2882-2889

4. Birnbaumer L 1990 Transduction of receptor signal into modulation of effector activity by $G$ proteins: the first 20 years or so. FASEB J 4:3068-3078

5. Alousi AA, Jasper JR, Insel PA, Motulsky HJ 1991 Stoichiometry of receptor$\mathrm{G}_{\mathrm{s}}$-adenylate cyclase interactions. FASEB J 5:2300-2303

6. Lau C, Burke JP, Slotkin TA 1982 Maturation of sympathetic neurotransmission in the rat heart. IX. Development of transsynaptic regulation of cardiac adrenergic sensitivity. J Pharmacol Exp Ther 223:675-680

7. Boreus LO, Hjemdahl P, Lagercrantz H, Martinsson A, Yao AC 1986 Badrenoreceptor function in white blood cells from newborn infants: no relation to plasma catecholamine levels. Pediatr Res 20:1152-1155

8. Slotkin TA, Kudlacz EM, Lappi SE, Tayyeb MI, Seidler FJ 1990 Fetal terbutaline exposure causes selective postnatal increases in cerebellar $\alpha$ adrenergic receptor binding. Life Sci 47:2051-2057

9. Habib DM, Padbury JF, Martinez AM, Chappell BA, Thio SL, Burnell EE 1991 Neonatal adaptation: cardiac adrenergic effector mechanisms after birth in newborn sheep. Pediatr Res 29:98-103

10. Oyama K, Padbury J, Chappell B, Martinez A, Stein H, Humme J 1991 Failure of prolonged intrauterine stress to alter beta adrenergic receptor mechanisms. FASEB J 279:7997(abstr)

11. Padbury JF, Ludlow JK, Ervin MG, Jacobs HC, Humme JA 1987 Thresholds for physiological effects of plasma catecholamines in fetal sheep. Am J Physiol 252:E530-E537

12. Martinez AM, Padbury JF, Humme JA, Evans CW, Shames L 1989 Plasma catecholamines and their physiologic thresholds during the first ten days of life in sheep. J Dev Physiol 13:141-146

13. Tomeh JF, Cryer PE 1980 Biphasic adrenergic modulation of B-adrenergic receptors in man. J Clin Invest 65:836-840

14. Peuler JD, Johnson GA 1977 Simultaneous single isotope radioenzymatic assay of plasma norepinephrine, epinephrine and dopamine. Life Sci 21:625636

15. Padbury JF, Klein AH, Polk DH, Lam RW, Hobel C, Fisher DA 1986 Effect of thyroid status on lung and heart beta-adrenergic receptors in fetal and newborn sheep. Dev Pharmacol Ther 9:44-53

16. Lowry OH, Rosebrough NJ, Farr AL, Randall RJ 1951 Protein measurement with folin phenol reagent. J Biol Chem 193:265-275

17. Klein AH, Jenkins JJ, Reviczky A, Fisher DA 1981 Thyroid hormone-sensitive brown adipose tissue respiration in the newborn rabbit. Am J Physiol 241:E449-E453 
18. Fiske $\mathrm{CH}$, Subbarow $\mathrm{Y} 1925$ The colorimetric determination of phosphorous. J Biol Chem 66:375-400

19. Clutter W, Bier DM, Shah SD, Cryer PE 1980 Epinephrine plasma metabolic clearance rates and physiologic thresholds for metabolic and hemodynamic actions in man. $\mathrm{J}$ Clin Invest 66:94-101

20. Munson P 1983 A computerized analysis of ligand binding data. Methods Enzymol 92:543-576

21. Tse J, Powell JR, Baste CA, Priest RE, Kuo JF 1979 Isoproterenol-induced cardiac hypertrophy: modifications in characteristics of $\beta$-adrenergic receptor, adenylate cyclase, and ventricular contraction. Endocrinology 105:246255

22. Vatner DE, Vatner SF, Nejima J, Uemura N, Susanni EE, Hintze TH, Homcy CJ 1989 Chronic norepinephrine elicits desensitization by uncoupling the $\beta$ receptor. J Clin Invest 84:1741-1748

23. DeBlasi A, Maisel AS, Feldman RD, Ziegler MG, Fratelli M, DiLallo M, Smith DA, Lai CC, Motulsky HJ 1986 In vivo regulation of beta-adrenergic receptors on human mononuclear leukocytes: assessment of receptor num- ber, location and function after posture change, exercise and isoproterenol infusion. J Clin Endocrinol Metab 63:847-853

24. Hayes JS, Pollock GD, Fuller RW 1984 In vivo cardiovascular responses to isoproterenol, dopamine and tyramine after prolonged infusion of isoproterenol. J Pharmacol Exp Ther 231:633-638

25. Brodde O-E, â Brinkman M, Schemuth, O'Hara N, Daul A 1985 Terbutalineinduced desensitization of human lymphocyte beta $_{2}$-adrenoreceptors. J Clin Invest 76:1096-1101

26. Feldman RD, Limbird JE, Nadeau J, FitzGerald A, Robertson D, Wood AJJ 1983 Dynamic regulation of leukocyte beta adrenergic receptor-agonist interactions by physiological changes in circulating catecholamines. J Clin Invest 72:164-170

27. Newnham JP, Lam RW, Hobel CJ, Padbury JF, Polk DH, Fisher DA 1986 Differential response of ovine placental lactogen levels in maternal and fetal circulations following single umbilical artery ligation in fetal sheep. Placenta 7:51-64

28. Bassett JM, Weeding CM, Hanson C 1990 Desensitization of $\beta$-receptor mediated responses to epinephrine in fetal lambs by prolonged ritodrine administration. Pediatr Res 28:388-390

\section{Announcement}

\section{NIH Treatment Study for Sydenham's Chorea}

Acutely ill patients with Sydenham's chorea are being sought for a controlled treatment study. Eligible patients will receive free diagnostic evaluation and treatment, including palliative medications, at the Child Psychiatry Branch of the National Institute of Mental Health in Bethesda, MD. The treatment study is an outgrowth of our long-term investigations of the sequelae of Sydenham's chorea. To participate, children should be at least 6 years old and acutely ill. There will be no expense to the patient (all treatment, travel, and lodging will be free of cost) and no remuneration. To refer a patient, contact Dr. Susan Swedo at (301) 496-6081, Building 10, Room 6N240, 9000 Rockville Pike, Bethesda, MD 20892, FAX (301) 402-0296. 